九州大学学術情報リポジトリ

Kyushu University Institutional Repository

\title{
Flow Patterns in Soybean Protein Isolate Melt in the Reservoir of an Extrusion Viscometer
}

Hayashi, Nobuyuki

Laboratory of Food Technology, Faculty of Agriculture, Kyushu University

Hayakawa, Isao

Laboratory of Food Technology, Faculty of Agriculture, Kyushu University

Fujio, Yusaku

Laboratory of Food Technology, Faculty of Agriculture, Kyushu University

https://doi.org/10.5109/23950

出版情報 : 九州大学大学院農学研究院紀要. 35 (1/2)，pp.59-64，1990-12. Kyushu University バージョン：

権利関係 : 


\title{
Flow Patterns in Soybean Protein Isolate Melt in the Reservoir of an Extrusion Viscometer
}

\author{
Nobuyuki Hayashi, Isao Hayakawa and Yusaku Fujio
}

Laboratory of Food Technology, Faculty of Agriculture, Kyushu University, 46-09, Fukuoka 812, Japan

(Received June 28, 1990)

\begin{abstract}
Flow patterns for soybean protein isolate (SPI) melt with low moisture content have been measured and revealed in the neighborhood of the entrance to a capillary die of the reservoir of an extrusion viscometer. The flow pattern of SPI melt was considerably depended on its moisture content. The secondary circulation flow was not observed in the flow pattern for SPI with moisture content below $23 \%$. The secondary flow was recognized for SPI with moisture content above $35 \%$ and the which was increased with the increase of the moisture content. As a result, it can be predicted that the fluid property of SPI melt could be dependent on its moisture content.
\end{abstract}

\section{INTRODUCTION}

The flow properties of protein melt were not yet fully elucidated in spite of their importance of present developments on extrusion cooking for a new food processing. Since the protein is first melted at a considerably high temperature and then texturized by cooling during the extrusion cooking process, the determination of the flow properties of the protein melt must thereby be important. On the other hand, the flow properties of the melt have been widely investigated for the various synthetic high polymers (Takahashi et al., 1985), such as polyethylene (Nakajima and Shida, 1955 ; Fujiyama and Kagiyama, 1972), Polystyrene (Rudin and Leeder, 1968 ; Kamal and Hyun, 1973), Polybutadiene (Bartos and Holomek, 1971) etc., which have been represented to a reasonable degree of approximation by the theory of isotropic viscoelastic fluids. In order to reveal the flow properties of the synthetic polymer melt, flow patterns in the synthetic polymer melts were also investigated in the neighborhood of the entrance to a capillary die of an extrusion rheometer (Bagley and Birks, 1959 ; Ballenger and White, 1970). Since the protein is a natural high polymer, the results on the studies with synthetic polymer should be comparable with that of natural biopolymer.

The purpose of the present paper is to describe an experimental study on the flow pattern of a vegetable protein (soybean protein isolate, SPI) melt at the velocity field in the neighborhood of the entrance to a capillary die in an extrusion viscometer.

Corresponding author : Yusaku Fujio 


\section{MATERIALS AND METHODS}

SPI and polystyrene

SPI powder was kindly supplied by Ajinomoto Co. Ltd. (Tokyo, Japan). The SPI composed of $87.7 \%$ protein (dry basis, Kjeldahl nitrogen $\times 5.71$ ) and $5.7 \%$ water. The moisture content of the SPI was adjusted to 17, 23, 29, 35 and $41 \%$ (wet basis) before use. Moisture adjustment was carried out by adding a calculated amount of fine ice powder (pulverized at $-20^{\circ} \mathrm{C}$ ) to the SPI and then by thoroughly mixing ($20^{\circ} \mathrm{C}$ ) them together with a mixer (MK-6000, National Electric Co. Ltd., Tokyo, Japan). The moisturized SPI was stored in a cold room at $5^{\circ} \mathrm{C}$ for $24 \mathrm{hrs}$ before use. Purified polystyrene (purchased from Katayama Chemicals Co. Ltd., Tokyo, Japan) was used as a reference of synthetic high polymer. The polystyrene shows glass transition temperature $(\mathrm{Tg})$ at $90.0^{\circ} \mathrm{C}$, number-average molecular weight $(\mathrm{Mn})$ of 97,000 and weightaverage molecular weight $(\mathrm{Mw})$ of 261,000 .

\section{Extrusion viscomter}

An extrusion viscometer (a proto-type, Shinmeiwa Seisakusho, Nishinomiya, Japan) mounted with a die (1.Omm in inner diameter and $20 \mathrm{~mm}$ in length) was used in present experiment. The sample reservoir of the extrusion viscometer was $60 \mathrm{~mm}$ in height (inner diameter, $11.28 \mathrm{~mm}$; cross-section area, $100 \mathrm{~mm}^{2}$ ). The temperature of the reservoir could be controlled at a desired temperature up to $200^{\circ} \mathrm{C}$ with a accuracy within $\pm 0.2^{\circ} \mathrm{C}$. The reservoir was also equipped with a cooling jacket using running water. Melt sample in the reservoir was extruded through the die with a plunger by hydraulic pressure. The plunger traveling speed was controlled utilizing a pre-set controller.

\section{Experimental steps}

The steps in obtaining flow pattern is shown in Fig. 1. A $0.4 \mathrm{~g}$ of the SPI and $0.05 \mathrm{~g}$ of the red colored SPI $(2.5 \mathrm{w} / \mathrm{w} \%$ Erythrosine-aluminium-lake mixture) was piled alternately up each other, repeatedly 9 for times and was pre-molded to a circular

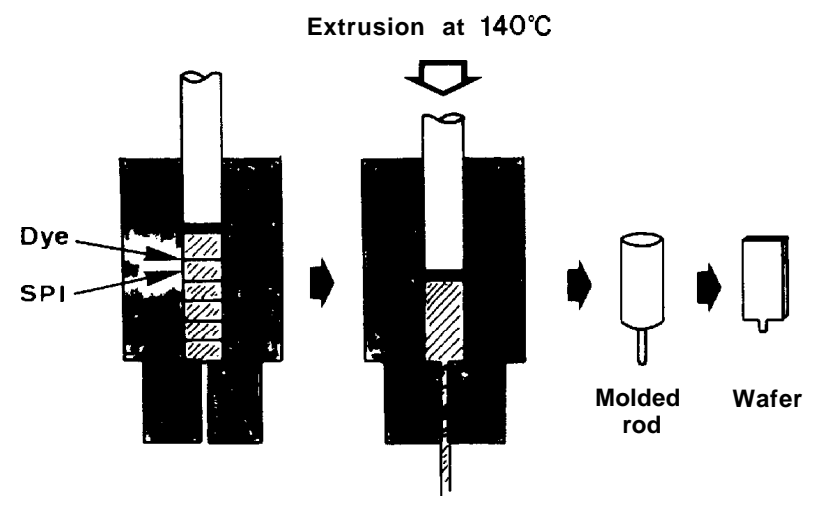

Fig. 1. Schematic diagram of sample preparation. 
cylinder $(10.8 \mathrm{~mm}$ in diameter, ca. $30 \mathrm{~mm}$ in height) with 9 thin red layer with a hand press. It was used as a specimen. The specimen was inserted into the sample reservoir and a plunger was mounted on the reservoir. The reservoir (pre-heated at $140^{\circ} \mathrm{C}$ ) was maintained at $140^{\circ} \mathrm{C}$ for $20 \mathrm{~min}$ and then extruded up to the traveling length of $15 \mathrm{~mm}$ of the plunger at a speed of $1.0 \mathrm{~mm} / \mathrm{sec}$. In the case of polystyrene, the same procedure was performed at $170^{\circ} \mathrm{C}$. After extrusion, the specimen was immediately cooled down to room temperature. The molded plug from the specimen in the reservoir was forced out. Eventually after removal of the plug, the longitudinal plane was picked out from the positions (the center portion of the plug) of the filament ends. The plug was ground flat on both side of this plane until a thin rectangular wafer remained containing a complete profile of flow pattern from plunger to die. Complete polishing of the wafer with a fine sand paper improved light transmittal and flow pattern clarity and an enlarged photograph was made out from the flow regions of interest.

\section{RESULTS}

\section{Entrance flow pattern obtained}

Figure 2 shows a typical flow pattern observed in SPI (B, $23 \%$; C, $35 \%$; D, $41 \%$ of moisture content) and polystyrene (A). The streamlines from all photographs obtained from the present experiments were schematically re-produced in Fig. 3. Although all stream lines in Fig. 3 were fundamentally exhibited its characteristics as

$A$

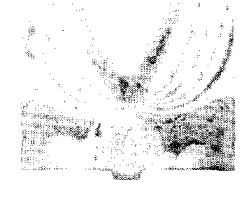

B

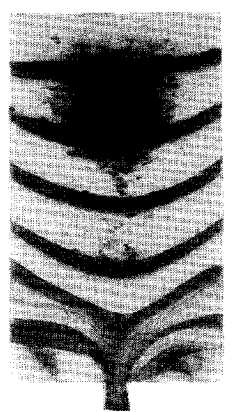

C

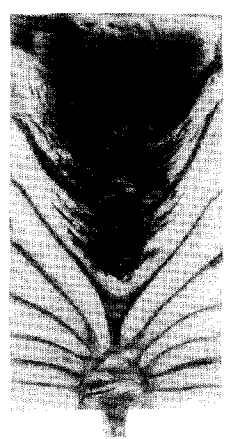

D

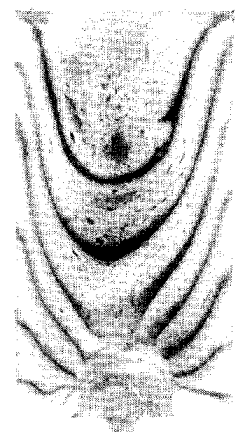

Fig. 2. Photographs of sample wafers.

A : I'S melt, B-D : SPI melts moisturized $23 \%, 29 \%$ and $41 \%$, respectively. 

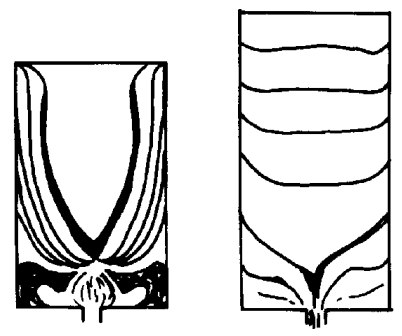

PS

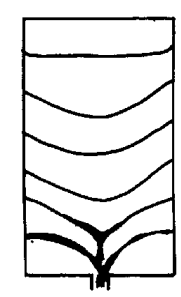

$23 \%$

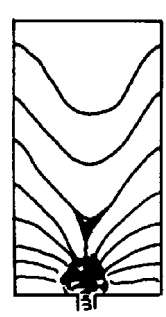

$29 \%$
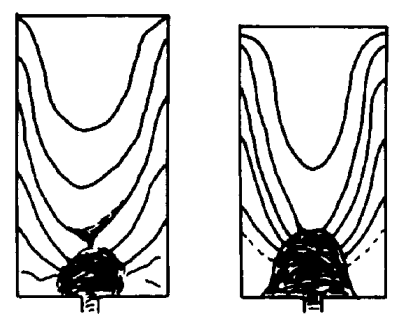

$35 \%$

$41 \%$

Fig. 3. The approximate flow profiles of SPI with various moisture contents and polystyrene in a reservoir with exit tube. PS; Polystyrene, Moisture contents of SPI varied from $17 \%$ to $41 \%$.

wine glass stem shape, it was however clearly obserbed that the stream lines for SPI with $23 \%$ moisture were considerably different from that for SPI with $29 \%$ in spite of the same flow rate. The flow of SPI below $23 \%$ moisture converges sharply into the capillary bounded by large stagnant region. It was also clear in the SPI pattern with moisture above $29 \%$ that a complex secondary circulation flow, like that of semi-spherical vortex, was formed just upon the capillary entrance and the region of the secondary flow was enlarged with the increase in moisture (Fig. 2 B-D). Flow of the region seemed to be completely different from the flow in other portions and there was thorough mixing. On the other hand, the stream lines of polystyrene were also quite different from that of SPI. The secondary circulation flow as shown in Fig. 2-A was spread over the bottom section and the secondary flow at the center portion just upon the capillary was sharply bounded by that of the outer portion.

\section{Secondary circular flow in SPI melt}

Secondary circular flow was formed for the SPI with moisture above $29 \%$ and the region was dependent on moisture content. Figure 4 shows the plot of moisture content of SPI against the ratio (as the measure of the secondary flow), s, of the height of the region to the reservoir diameter $(11.28 \mathrm{~mm})$. As shown in Fig. 3, the secondary circulation flow was not recognized at a moisture content of $23 \%$ but it was suddenly evident at moisture content of $29 \%$. As a result, the fluid property of SPI melt was dependent on its moisture content and the critical changing point was between 23-29 $\%$ of moisture content. This phenomenon seems to be an important fact that in expounding the fluid/flow property of SPI melt with low moisture content.

\section{DISCUSSION}

In order to elucidate the structure of the velocity field in the neighborhood of the entrance to a capillary die, the flow patterns on several synthetic polymer melts have been investigated using the almost the same method as the present research. In the case of synthetic polymer melts, the secondary circulation flow, a plane perpendicular 


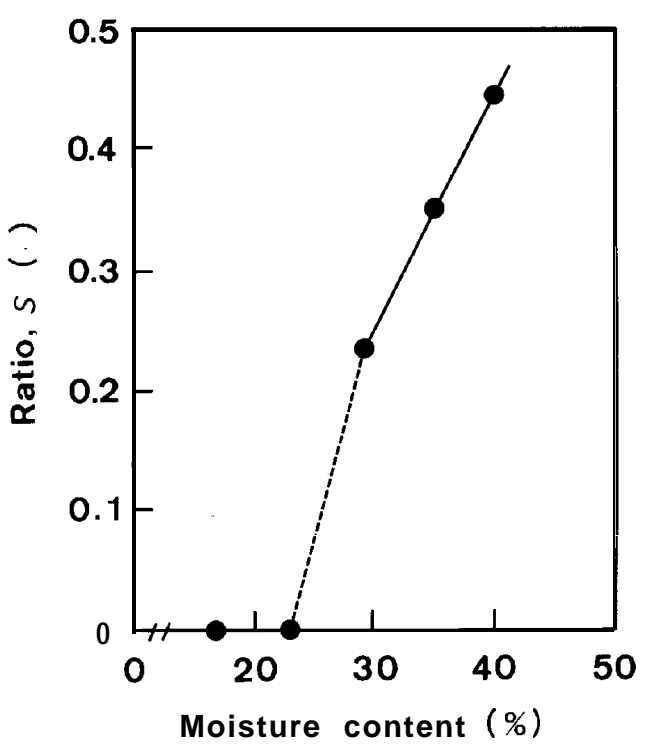

Fig. 4. Relationship between the moisture content of SPI and the ratio, s, of the height of the secondary flow region to the reservoir diameter.

to the normal parallel streamlines as mentioned in text, were predicted on laminar rectilinear flow through an conical duct (Kaloni, 1965a), converging channel (Kaloni, 1965b) and converging flow at a capillary (Bagley and Birks, 1960 ; Ballenger and White, 1970). It is believed, as a result, that the cause of these secondary flows in viscoelastic fluids is the existence of incompatiblities in the equation of motion for a parallel streamline flow situation caused by the presence of normal stresses which are absent in Newtonian fluids. On the other hand, the present experiment yielded a quite different secondary flow by SPI melt compared with that of synthetic polymer melt as shown in Fig. 1. In the case of SPI melt, the secondary flow behavior was divided into two phenomena depending on its moisture content. However, the fluid property of SPI melt was not fully evident now in spite of its being a polymer material. Yet the difference between synthetic polymer melt and the natural bio-polymer, although not directly compared, was quite expressed.

We can conclude from the present experiment that the fluid property of SPI melt, quite different from that of synthetic polymer melt, changes according to its moisture content. Since the accepted knowledge for synthetic polymer melt could be used in the case of natural bio-polymer melt, we must further investigate bio-polymer melt based on synthetic polymer melt in the future.

\section{REFERENCES}

Bagley, E. B. and A. M. Birks 1960 Flow of polyethylene into a capillary. J.Appl. Physics, $31: 556$ 
$-561$

Ballenger, T. F. and J. L. Whithe 1970 An experimental study of flow patterns in polymer fluids in the reservoir of a capillary rheometer. Chem.Eng. Sci., $25: 1191-1195$

Bartos, 0 and J. Holomek 1971 Unstable flow amorphous polymers through capillaries I. Velocity profiles of polymer having discontinuous flow curve. Poly. Eng. Sci., 11 : 324-334

Fujiyama, M and Y. Kagiyama 1972 Melt rheology of high-density polyethylene. J. Appl. Poly. Sci., $16: 3361-3373$

Kajiyama, N and M. Shida 1966 Viscoelastic behavior of polyethylene in capillary flow expressed with three material functions Trans. Soc.Rheology, 10 : 299-316

Kaloni, P. N. 1965a On creeping flow of a visco-elastic liquid in converging channel. J. Phys. Soc., Japan, $20: 132-138$

Kaloni, P. N. 1965b On the flow of an elastic-viscous fluid in a conical duct. J. Phys. Soc. Japan, 20: $610-616$

Kamal, M. R. and H. Hyun 1973 The effect of pressure on the shear viscosity of polymer melts. Trans. Soc. Rheology, $172: 271-285$

Nakajima, N. and M. Shida 1966 Viscoelastic behavior of polystyrene in capillary flow expressed with three material functions. Trans. Soc. Rheology, 10 : 299-316

Rudin, A and D. R. Leeder 1968 Time-dependent capillary flow of polystyrene. J.Appl.Poly. Sci., $12: 2305-2316$

Takahashi, H, T. Matsuoka and T. Kurauchi 1985 Rheology of polymer melts in high shear rate. J. Appl.Poly. Sci., 30 : 4669-4684 